\title{
Influence of weather parameters on population dynamics of thrips and mites on summer season cowpea in Eastern Plateau and Hill region of India
}

\author{
MOANARO and JAIPAL SINGH CHOUDHARY* \\ ICAR Research Complex for Eastern Region, Research Centre, Ranchi, Jharkhand 834010 \\ *Email: choudhary.jaipal@gmail.com
}

\begin{abstract}
Population dynamics of thrips, Megaleurothrips distalis (Karny) and mites, Tetranychus spp. were studied on summer season cowpea crop during 2013-2014 in Eastern Plateau and Hill region of India. Temperature, rainfall and host-plants were analyzed with respect to population fluctuation of pests. The population of thrips and mites were observed from low to high throughout the entire season and the incidence were more or less in the same pattern of the population fluctuation. Infestation of both thrips and mite initiated from $2^{\text {nd }}$ week of March and continued up to the last week of June. The correlation analysis between thrips population and weather parameters indicated a strong significant positive correlation between the number of thrips and maximum temperature $(p \leq 0.01)$ and significant with the mean temperature $(p \leq 0.05)$. A significant negative correlation was observed between thrips population and rainfall, but a negative correlation with $\mathrm{RH}$ was found to be non-significant. Similarly, temperature showed positive and rainfall a negative correlation on mite population fluctuation. The linear regression model based on weather conditions as independent variable and thrips and mites population fluctuation as dependent variable, explained to 72 percent for thrips and 62 percent for mite population variability. Environmental factors played significant role in distribution and abundance of thrips and mites population.
\end{abstract}

Key words: Correlation, mites, population dynamics, cowpea.

Cowpea [Vigna unguiculata Linn. (Walpers)], a leguminous crop cultivated throughout the tropics and subtropics countries between $35^{\circ} \mathrm{N}$ to $30^{\circ} \mathrm{S}$ both for vegetable and pulse. It is severely damaged by two-spotted spider mite, Tetranychus urticae Koch; whitefly, Bemisia tabaci (Genn.); leafhopper, Empoasca discipinens Padi; thrips, Megaleurothrips spp. and the aphid, Aphis craccivora Koch in different parts of the world (Abdel-Alim, 1994). Thrips species complex (Megaleurothrips distalis, M. usitatus and Thrips palmi) (Thysanoptera: Thripidae) damage is caused by feeding through scrapping on content of individual plant cells which consequently reduce the photosynthetic capacity (Shipp et al., 2000). Losses caused by thrips to petal and fruit malformation and scarring are of even greater economic importance (Zhang et al., 2007). Flowering stage of the crops is particularly vulnerable to attack of this pest. Thrips occur every growing season and cause yield losses through premature dropping of flowers. Even though, pod necrosis caused by feeding and oviposition can significantly reduce the market value of crops. Mites, Tetranychus urticae also feeds on plant cell content in the underside of the leaves which gives the upper surface of the leaves to whitish or yellowish stippling characteristic. Ultimate effects of feeding include decrease in photosynthesis and transpiration activity leading to reduction in the amount of harvestable yield.

In India, $M$. distalis species of thrips and T. urticae species of mites are reported to be the most predominant (Chakraborty et al., 2014; Ghosh, 2013). The incidence and development of all the insect pests are much dependent upon the prevailing environmental conditions such as temperature, relative humidity and precipitation (Woiwod, 1997). Published informations on population dynamics and factors influencing population of thrips and mites on cowpea is scanty and incomplete especially in Eastern Plateau and Hill (EPH) region of India where it is totally lacking. Hence, the present study was carried out with the objectives as (i) to analyze the population dynamics of thrips and mites on cowpea in EPH region conditions and (ii) to analyze factors that affect the population dynamics. Keeping these views in mind, analysis on these issues in the region will provide essential information for understanding the population dynamics of thrips and mites in the whole region.

\section{MATERIALS AND METHODS}

The test cowpea genotypes viz., Swarna Sweta, Swarna Harita and Swarna Mukut were sown at the research farm of ICAR Research complex for Eastern Region, Research 


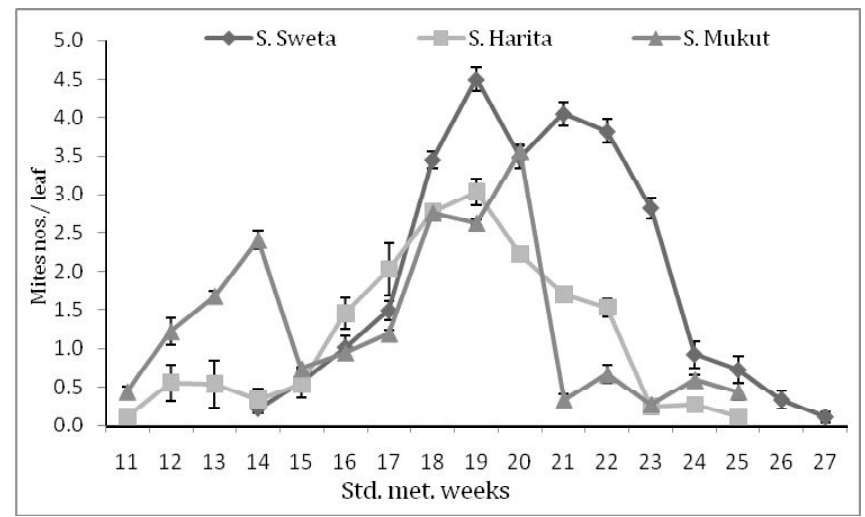

Fig 1 : Thrips population dynamics (pooled) on different genotypes of cowpea observed on different standard meteorological weeks

Centre, Ranchi, $\left(23^{\circ} 45^{\prime} \mathrm{N}, 85^{\circ} 30^{\prime} \mathrm{E}\right.$, Altitude $620 \mathrm{~m}$ above $\left.\mathrm{msl}\right)$ Jharkhand, during the two successive growing summer seasons (2013 and 2014). Seeds were dibbled at a spacing of $40 \mathrm{~cm}$ on raised beds in randomized block design, with three replicates with a plot size of $4 \mathrm{~m}^{2}$ under drip irrigation system in the first week of February. The distance between two laterals was maintained at $1 \mathrm{~m}$. All the post-sowing agronomic practices except plant protection were followed as per recommended package and practices for summer season cowpea crop.

The species of thrips was determined as Megaleurothrips distalis Karny and that of red spider mites as Tetranychus spp. based on the morphological descriptions given by Diffie et al., (2008). The population of red spider mite from one leaf each from top, middle and bottom of the selected plants and that of thrips by tapping leaf/bud/ flower once from each of the selected plants in the morning hours were recorded at weekly interval. Five randomly selected plants in each replication of each variety were considered for population counting purpose. Data on population of both the pests were recorded from the first appearance to till maturity of the crop. The data on weather parameters viz., minimum and maximum temperature $\left({ }^{\circ} \mathrm{C}\right)$, relative humidity $(\mathrm{RH})(\%)$ and rainfall $(\mathrm{mm})$ were collected from the agro-meteorological observatory of the Centre. The mean and simple correlation and regression were calculated by using SPSS V.16 in order to find out the effect of different weather parameters on the incidence and development of thrips and mites on the cowpea crop. The figures in the article were drawn using Microsoft office excel 2007.

\section{RESULTS AND DISCUSSION}

\section{Population dynamics}

Mean pooled population of thrips, M. distalis and

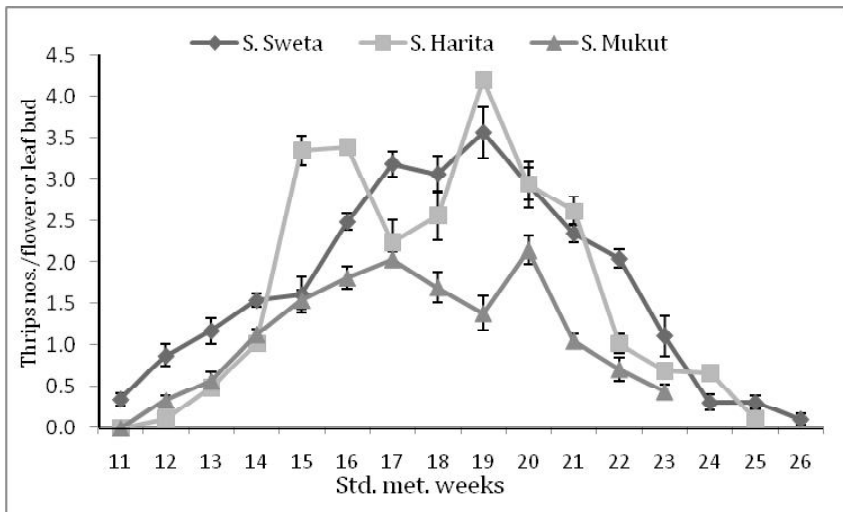

Fig 2 : Mite population dynamics (Pooled) on different genotypes of cowpea observed on different standard meteorological weeks

mites, Tetranychus spp. at various stages on all the three genotypes of cowpea recorded from the first incidence to till end of crop harvesting are summarized in Fig. 1 and 2. Both the thrips and mites population were observed low to high in the entire cropping season of cowpea. The incidences of both the pests were also more or less same in the pattern of population fluctuation on all the genotypes. The infestation of both the pests initiated from the second week of March and continued up to the last week of June. The pattern of pooled population of thrips was noticed from 0.11 to 3.57 per leaf in Swarna Sweta, 0.11 to 4.20 per leaf in Swarna Harita and 0.33 to 2.14 per leaf in Swarna Mukut and for mites, it was observed in the range from 0.11 to 4.50 per leaf in Swarna Sweta, 0.11 to 3.03 in Swarna Harita and 0.33 to 2.14 per leaf in Swarna Mukut. Patel et al. (2010) also noticed Megaleurothrips spp. in the month of March onward in cowpea. The peak of population was reached at flowering time of the crop on all the studied genotypes. Presence of flowers on the crop provides conducive environment for perpetuating thrips through quality feeding and breeding place (Buitenhuis and Shipp, 2007). Population build up of mites on cowpea in this region is in accordance with the buildup of mites population in Varanasi region where it also started from second week of March and the highest population buildup of mites were recorded on $18^{\text {th }}$ and $20^{\text {th }}$ standard weeks (Kumar et al., 2014).

\section{Relationship between population and weather factors}

Weather factors were one of the important factors that influenced the fluctuation of population of thrips and mites. The data on correlation between pooled incidence of thrips and mites population with weather parameters showed significant relationship as presented in Table 1. The correlation analysis indicated a strong significant positive correlation between the number of thrips per tap and maximum 
Table 1 : Influence of weather parameters on Thrips, Megalurothrips distalis Karny and Mite, Tetranychus spp., population dynamics (Pooled 2013 and 2014)

\begin{tabular}{|c|c|c|c|c|c|c|c|c|c|c|}
\hline \multirow[t]{2}{*}{ Varieties/overall } & \multicolumn{2}{|c|}{ Min Temp. } & \multicolumn{2}{|c|}{ Max Temp. } & \multicolumn{2}{|c|}{ Mean Temp. } & \multicolumn{2}{|c|}{ Relative humidity } & \multicolumn{2}{|c|}{ Rainfall } \\
\hline & Thrips & Mites & Thrips & $\overline{\text { Mites }}$ & Thrips & Mites & Thrips & Mites & Thrips & Mites \\
\hline Swarna Sweta & 0.05 & 0.25 & $0.71 * *$ & $0.52 *$ & $0.42 *$ & $0.63 * *$ & -0.18 & 0.36 & $-0.58 *$ & $-0.45^{*}$ \\
\hline Swarna Harita & 0.24 & 0.32 & $0.81 * *$ & $0.70 * *$ & $0.68 * *$ & $0.65^{*}$ & -0.08 & 0.07 & -0.35 & -0.38 \\
\hline Swarna Mukut & 0.33 & -0.06 & $0.73 * *$ & $0.54^{*}$ & $0.62 * *$ & 0.30 & -0.09 & -0.06 & -0.41 & $-0.43^{*}$ \\
\hline Overall & 0.05 & 0.32 & $0.80 * *$ & $0.63 *$ & $0.48^{*}$ & $0.61 *$ & -0.23 & 0.28 & $-0.54^{*}$ & $-0.45^{*}$ \\
\hline
\end{tabular}

* Significant at $\mathrm{P} \leq 0.05 ; * *$ Significant at $\mathrm{P} \leq 0.01 ; n=15$

Table 2: Regression model using thrips and mite populations and abiotic factors (Pooled)

\begin{tabular}{lll}
\hline Pest species & Regression equations & $\mathrm{R}^{2}$ \\
\hline Thrips & $\mathrm{Y}=-9.17^{*}+\left(0.008 \mathrm{~T}_{\min }\right)+\left(0.27 \mathrm{~T}_{\mathrm{Max}}\right)+(0.01 \mathrm{RH})-(0.01 \mathrm{RF})+0.63^{* *}$ & 0.72 \\
Mites & $\mathrm{Y}=-8.34^{*}+\left(0.11 \mathrm{~T}_{\min }\right)+\left(0.10 \mathrm{~T}_{\mathrm{Max}}\right)-(0.04 \mathrm{RH})-(0.01 \mathrm{RF})+0.77^{* *}$ & 0.62 \\
\hline
\end{tabular}

*values denotes constant estimated from the data; ** random error term

temperature $(\mathrm{p} \leq 0.01)$ and significant with the mean temperature $(\mathrm{p} \leq 0.05)$ (Table 1). Earlier studies also explained that thrips population on different crops are positively influenced by temperature and population density increased with increasing temperature (Patel et al., 2010). Asignificant negative correlation was found with the thrips population and rainfall, even though a negative correlation was observed with RH, it was found to be non-significant. Results are in line with earlier reports (Khan and Ullah, 1994). Overall, temperature had positive correlation with thrips incidence while $\mathrm{RH}$ and rainfall gave a negative correlation in this study. In extreme high temperature region, thrips population was found to be retarded on high temperature with low relative humidity (Dintenfass et al., 1987). Based on region specific findings, some are not supportive to the present findings (Panikar and Patel, 2001). Considering multiple factors influencing population of thrips as dependent variable and weather conditions as independent variable, linear regression analysis was carried out and presented in Table 2. The linear regression model based on weather variables could explain 60 to $68 \%$ variability on thrips population fluctuation on the studied varieties. When it was combined on all varieties it reached to $72 \%$ explaining the thrips population variability.

Similarly, temperature showed positive and rainfall a negative correlation on mite population fluctuation (Table 1). Chinniah et al. (2007) in their study also revealed that the maximum temperature had significant positive correlation with two spotted spider mite population dynamics where as rainfall had a significant negative correlation with two spotted spider mite population. Most of the studies showed that temperature has positive and rainfall a negative relation with mite population in the majority of the conditions (Meena et al., 2013; Dhar et al., 2000). The present findings concord with the findings of Chavan et al., (2003) who reported a significant and positive correlation of mites population with temperature and a negative correlation with rainfall. Considering multiple factors influencing population of thrips as dependent variable and weather conditions as independent variable, linear regression analysis was carried out and presented in Table 2. The linear regression model based on weather conditions as independent variable and mites population fluctuation as dependent variable, which explained 41 to $59 \%$ of the variability in the mites population fluctuation on the studied varieties. When it was combined on all the varieties, it reached to $62 \%$ explanation of mite population variability. So, it is suggested that increase in population density of mites were associated with high temperature and low humidity and temperature appeared to be the regulatory factor for population buildup of mite pest.

\section{CONCLUSION}

It can be concluded that weather factors have regulatory roles for thrips and mites population build up in summer season grown cowpea in EPH region of India. These data also suggest that sowing dates can be adjusted in order to save cowpea crop from severe attack of insect pests reported in this study.

\section{ACKNOWLEDGEMENT}

Authors would like to thank Director of ICAR 
Research complex for Eastern Region, Dr. B.P. Bhatt and Head of the Centre and Dr A.K. Singh for providing all necessary infrastructure facilities to perform this research work. We are thankful and indebted to Dr. R.S. Pan for allowing us to conduct this study in his experimental plot and his invaluable suggestions while writing the manuscript.

\section{REFERENCES}

Abdel-Alim,A. A. (1994). Ecological studies on certain insects infesting cowpea plants in Minia region. J. Agric. Res. \&Dev, 16(2): 261-274.

Buitenhuis, R. and J.L. Shipp. (2007). Influence of plant growth stage on Frankliniella occidentalis pupation behaviour in greenhouse ornamentals. J. Appl. Entomol., 132: 8688.

Chakraborty, S., N. Chaudhuri and S.K. Senapati. (2014). Evaluation of mung bean genotypes against thrips (Megaleurothrips distalis) in Terai region of West Bengal, India. Ecol, Env. And Res. (Supplement Issue Dec.): $149-154$.

Chavan, B.P., J. R. Kadam, and H. R. Koli. (2003)Effects of dates of sowing on incidence of red spider mite, Tetranychus cinnabarinus (Boisd) infesting okra. Proceeding of State Level Seminar on Pest Management for Sustainable Agriculture. February, 6-7, 2003, Marathwada Agricultural University, Parbhani(M.S.) India, 187-188.

Chinniah, C., S. Balaji, K. K. Mararagatham and C. Muthiah. (2007-). Influence of weather parameters on the population dynamics of red spider mite Tetranychus urticae on okra Abelmoschus esculentus (L.) Moench. J. Acarol., 16: 45-46.

Dhar, T., P.K. Dey and P.K. Sarkar. (2000) Influence of abiotic factors on population build-up of red spider mite, Tetranychus urticae on okra vis a vis evaluation of some new pesticides for their control. Pestol., 24(9): 3437.

Diffie, S., Funderburk, J., Goldarazena, A., and Mound, I. (2008). New North American records for two Oriental thrips (Thysanoptera) species. J. Entomol. Sci. 43(1): 128-132
Dintenfass, L.P., D.P. Bartell and M.A. Scott.(1987). Predicting resurgence of Western Flower Thrips (Thysanoptera: Thripidae) on onion after insecticide application in the Texas high plains. J. Econ. Ent., 80:502-506.

Ghosh, S. K. (2013). Incidence of Tetranychus cinnabarinus infestation on different varieties of Abelmoschus esculentus. Curr. Biotica, 7(1\&2): 40-50.

Khan, S. M. and Z. Ullah. (1994). Population dynamics of insect pests of cotton in Dera Ismail Khan. Sarhad. J. Agri., 10(3): 285-290.

Kumar, D., M. Raghuraman and J. Singh. (2014). Impact of abiotic factors on population dynamics of phytophagous mite (Tetranychus ludeni zacher) on cowpea in eastern Uttar Pradesh. The Ecoscan, 8(1\&2): 07-09.

Meena, R. S., O. P. Ameta and B. L. Meena. (2013). Population dynamics of sucking pests and their correlation with weather parameters in chilli, Capsicum annum L. crop. The Bioscan, 8(1): 177-18.

Panikar, B. K. and J. R. Patel. (2001). Population dynamics of thrips on chilli, cotton and pigeon pea. Indian J. Entomol., 63(2): 170-175.

Patel, S. K., B. H. Patel, D. M. Korat and M. R. Dabhi. (2010). Seasonal incidence of major insect pests of cowpea, Vigna unguiculata (Linn.) Walpers in relation to weather parameters. Karnataka J. Agric. Sci., 23(3) 497-499.

Shipp, J.L., K. Wang and M.R. Binns. (2000). Economic injury levels of western flower thrips(Thysanoptera: Thripidae) on greenhouse cucumber. J. Econ. Entomol., 93(6): 1732-1740.

Woiwod, I. (1997). Detecting the effects of climate change on Lepidoptera. J. Insect Conserv., 1(3): 149-158.

Zhang, Z. J., Q.J. Wu, X. F.Li, Y.J. Zhang, B. YXu and G.R.Zhu. (2007). Life history of western flower thrips, Frankliniella occidentalis (Thysan., Thripidae), on five different vegetable leaves. J. Applied Ent., 131(5): 347-354. 